\title{
Quality assurance in European pharmacy education and training ${ }^{*}$
}

*Based on the results of the survey carried out under work program 6 of the PHARMINE project (Pharmacy Education in Europe, www.pharmine.org) funded by the European Union.

Jose A. GUIMARÃES MORAIS, Afonso M. CAVACO, Bart ROMBAUT, Michael J. ROUSE, Jeffrey ATKINSON. Received (first version): 30-Nov-2011 Accepted: 1-Dec-2011

\begin{abstract}
${ }^{*}$
A survey of quality assurance (QA) systems in European faculties of pharmacy was carried out under the auspices of the European Association of Faculties of Pharmacy PHARMINE consortium. A questionnaire based on the quality criteria of the International Pharmaceutical Federation and the Accreditation Council for Pharmacy Education (USA) was sent out to European faculties. Replies were obtained from 28 countries. Just above half has a working QA system. QA scores were high concerning matters such as complete curriculum and training, use of European Credit Transfer System, students' representation and promotion of professional behavior. QA scores were low concerning matters such as evaluation of achievement of mission and goals, and financial resources. The PHARMINE consortium now has a basis upon which to elaborate and promote $Q A$ in European pharmacy faculties.
\end{abstract}

Keywords: Education, Pharmacy. Quality Control. European Union. Europe.

\section{ASEGURAMIENTO DE LA CALIDAD EN LA EDUCACIÓN Y FORMACIÓN EN FARMACIA EN EUROPA}

\section{RESUMEN}

Se realizó bajo los auspicios del consorcio PHARMINE de la Asociación Europea de Facultades de Farmacia una encuesta sobre los sistemas de aseguramiento de la calidad (QA) en las facultades de farmacia europeas. Se envió a las facultades europeas un cuestionario basado en los criterios de calidad de la Federación Internacional de Farmacia y el Consejo de Acreditación para la Educación en Farmacia (USA). Se obtuvieron respuestas de 28 países. Ligeramente más de la mitad tiene un sistema en funcionamiento de QA. Las puntuaciones de QA fueron altas en asuntos como currículo y formación completo, uso del Sistema Europeo de Transferencia de Créditos, representación de los estudiantes y promoción de la actuación profesional. Las puntuaciones de QA fueron bajas en asuntos como la evaluación de la consecución de misión y metas y recursos financieros. El consorcio PHARMINE tiene ahora una base sobre la que elaborar y promover la QA en las facultades de farmacia europeas.

Palabras clave: Educación en Farmacia. Control de Calidad. Unión Europea. Europa.

\section{INTRODUCTION}

The PHARMINE work program 6 on quality assurance (QA) aimed to identify the key elements of QA in European pharmacy education by surveying higher education institutes (HEls) that are members of the European Association of Faculties of Pharmacy (EAFP, www.eafponline.org): Belgium, Bulgaria, Czech Republic, Denmark, Estonia, Finland, France, , Germany, Greece, Hungary, Iceland, Ireland, Italy, Latvia, Lithuania, Macedonia (FYROM), Malta, Norway, Poland, Portugal, Romania, Serbia, Slovakia, Slovenia, Spain, The Netherlands, Turkey and the UK. The survey was carried out using an electronic survey form.

\section{METHODS}

A questionnaire was produced based on the quality criteria recommended by the International Pharmaceutical Federation, FIP: 'A Global Framework for Quality Assurance of Pharmacy 
Education':

http://www.fip.org/www/uploads/database file.php?i $\mathrm{d}=302 \&$ table id $=$ and the 'Accreditation Standards and Guidelines for the Professional Program in Pharmacy Leading to the Doctor of Pharmacy Degree' of the Accreditation Council for Pharmacy Education (ACPE, USA): http://www.acpeaccredit.org/standards/standards1.asp

The QA areas surveyed were:

1. The existence of QA for education and research in the country and its model;

2. Mission, planning and evaluation

3. Organization and administration

4. Curriculum

5. Students

6. Faculty Staff

\section{Facilities and Resources}

The distribution of an empirical QA indicator was calculated assuming that all questions in the survey were indispensible elements for a QA system, with each survey item equalling 1 point giving a maximum or ideal score of 33 points. Although items may present in practice different weights, related to how critical the presence of a certain QA element is, this indicator reflects the level of compliance with a sound and complete QA system.

\section{RESULTS}

A total of 28 countries replied to the QA survey (see list above). Just above half has a QA system that is implemented (table 1). For participants with a QA system, a combination of internal and external systems was prevalent.

Concerning the QA areas, most replies were globally positive with positive response rates of $70 \%$ or over. Items with lower scores were: evaluation of achievement of mission and goals, and financial resources. Thus the most frequent issue was the lack of adequate financial resources.

The distribution of the empirical QA indicator shows that 8 countries have scores of 30 or more out of a maximum of 33 quality related items, while only 2 have a minimum of 22 items (table 2). Most countries (12) were located in middle of this distribution with scores of 28 or 29 .

\section{DISCUSSION}

A QA system exists in most European countries. Albeit the fundamental principles of $Q A$ are not necessarily followed. The absence of a mission statement with evaluation shows a lack of QA culture in some HEls. Although all HEls are aware of a QA policy as a means to assure better educational and research outcomes, it seems necessary to develop this further.

There are areas in which all HEls believed they were performing according to QA requirements: complete curriculum and training, transfer of ECTS, students' representation and promotion of professional behavior. These are the pillars of any $\mathrm{HEI}$ that graduates health professionals. However, HEls in pharmacy education seem to suffer from several constraints. There are financial pressures, and these may lead to limitations in autonomy within the global university structure, non-adapted facilities, as well as to restrictions on staff with a consequent reduction in continuing professional development and other activities.

Although a QA system does involve costs, it is a good way of picking up weaknesses and strengths in HEls, with the possibility to establish realistic and feasible plans to improve structures, processes and outcomes in HEls, thus promoting recognition and additional funding.

This study had certain limitations. It was not possible to confirm if participants were referring to their $\mathrm{HEI}$ or to the general situation in their country. The quality of the data collected was not evaluated.

\section{Future perspectives}

The results reveal good opportunities to further explore QA systems in European faculties leading to the construction of a Pan-European Accreditation System. Furthermore this survey constitutes a starting point for the elaboration of recommendations on accreditation procedures for pharmacy faculties.

\section{ACKNOWLEDGEMENTS}

With the support of the Lifelong Learning Programme of the European Union: 142078-LLP-12008-BE-ERASMUS-ECDSP and the European Association of Faculties of Pharmacy (EAFP), Belgium.

The authors thank the following members of the PHARMINE ("PHARMacy Education IN Europe") consortium:

C. NOE, University of Vienna, AUSTRIA.

B. ROMBAUT, H. HALEWIJCK and B. THYS, Vrije Universiteit Brussel, Faculty of Medicine and Pharmacy, Dept. Pharmaceutical Biotechnology and Molecular Biology, BELGIUM.

V. PETKOVA and S. NIKOLOV, University of Sofia, Faculty of Pharmacy; V. BELCHEVA, SanofiAventis, BULGARIA.

M. POLASEK, Faculty of Pharmacy, Charles University, CZECH REPUBLIC.

U. MADSEN and B. FJALLAND, Faculty of Pharmaceutical Sciences, University of Copenhagen; M. BRANDL, Faculty of Science, University of Southern Denmark; $M$. RINGKJØBING-ELEMA, EIPG / The Association of Danish Industrial Pharmacists, DENMARK.

P. VESKI and D. VOLMER, Department of Pharmacy, University of Tartu, ESTONIA.

J. HIRVONEN and A. JUPPO, University of Helsinki, Faculty of Pharmacy, FINLAND. 
C. CAPDEVILLE-ATKINSON, Nancy University, FRANCE; A. MARCINCAL, Faculté de Pharmacie, Université de Lille 2; V. LACAMOIRE and I. BARON, Conseil National de l'Ordre des Pharmaciens, FRANCE.

R. SÜSS and R. SCHUBERT, University of Freiburg, GERMANY.

P. MACHERAS, E. MIKROS and D. M. REKKAS, School of Pharmacy, University of Athens; K. POULAS, School of Pharmacy, University of Patras, GREECE.

G. SOOS and P. DORO, Faculty of Pharmacy, University of Szeged, HUNGARY.

T. KRISTMUNDSDOTTIR and A. B. ALMARSDOTTIR, Faculty of Pharmaceutical Sciences, University of Iceland, ICELAND.

J. STRAWBRIDGE and P. GALLAGHER, Royal College of Surgeons in Ireland, Dublin; L. HORGAN, Pharmaceutical Society of Ireland, PSI The Pharmacy Regulator, IRELAND.

C. ROSSI, and P. BLASI Faculty of Pharmacy, University of Perugia, ITALY.

R. MUCENIECE, Faculty of Medicine of University of Latvia; B. MAURINA, Faculty of Pharmacy; I. SAPROVSKA, Latvian Branch, European Industrial Pharmacists' Group (EIPG), LATVIA.

V. BRIEDIS and M. SAPRAGONIENE, Lithuanian University of Health Sciences, LITHUANIA.

L. M. AZZOPARDI and A. S. INGLOTT, University of Malta, Department of Pharmacy, MALTA.

T. SCHALEKAMP, Utrecht University, Faculty of Science, Department of Pharmaceutical Sciences; H. J. HAISMA, University of Groningen, School of Life Sciences, Pharmacy and Pharmaceutical Sciences, THE NETHERLANDS.

K. M. ULSHAGEN, P. H. TUSVIK, L. TRELNES, Farmasøytisk Institutt, NORWAY.
S. POLAK and R. JACHOWICZ, Faculty of Pharmacy with Division of Medicinal Analysis, Jagiellonian University Medical College, POLAND.

J. A. G. MORAIS and A.M. CAVACO, Faculdade de Farmácia Universidade de Lisboa, PORTUGAL.

C. MIRCIOIU and C. RAIS, Faculty of Pharmacy, University of Medicine and Pharmacy "Carol Davila", ROMANIA.

J. KYSELOVIČ and M. REMKO, Faculty of Pharmacy, Comenius University, Odbojarov 10, Bratislava, 83232, SLOVAKIA.

B. BOZIC and S. GOBEC, University of Ljubljana, Faculty of Pharmacy, SLOVENIA.

B. DEL CASTILLO-GARCIA, Facultad de Farmacia, Universidad Complutense de Madrid; L. RECALDE and A. SANCHEZ POZO, Facultad de Farmacia, Universidad de Granada, SPAIN.

R. HANSSON and E. BJÖRK, Faculty of Pharmacy, Uppsala University; G. TOBIN, Sahlgrenska Academy, SWEDEN.

F. HINCAL and L. O. DEMIREZER, Hacettepe University Faculty of Pharmacy, Department of Pharmaceutical Toxicology, TURKEY.

K. A WILSON, Aston Pharmacy School, Aston Triangle; G.B.LOCKWOOD, University of Manchester, School of Pharmacy \& Pharmaceutical Sciences., UNITED KINGDOM.

J. CHAVE, General Secretary, PGEU, Pharmaceutical Group of the European Union.

J. NICHOLSON, General Secretary; EIPG, European Industrial Pharmacists Group.

R. FRONTINI, President; EAHP, European Association of Hospital Pharmacists.

The President, EPSA, European Pharmaceutical Students' Association. 


\begin{tabular}{|c|c|c|}
\hline & Questions & $\begin{array}{l}\text { Yes } \\
(\%)\end{array}$ \\
\hline \multicolumn{3}{|l|}{ Quality Assurance (QA) } \\
\hline & $\begin{array}{l}\text { Does your Higher Education Institution (HEI) have a Quality Assurance (QA) } \\
\text { system? }\end{array}$ & 60 \\
\hline & Is the QA system up-to-date and implemented? & 57 \\
\hline & $\begin{array}{l}\text { Please indicate whether your system is } \\
\text { (a) Internal to the HEI } \\
\text { (b) External to the HEI } \\
\text { (c) A combination of both }\end{array}$ & $\begin{array}{l}17 \\
3 \\
40\end{array}$ \\
\hline \multicolumn{3}{|c|}{ Mission, Planning and Evaluation } \\
\hline Mission & $\begin{array}{l}\text { Has your faculty a published statement of its mission in all of the following topics: } \\
\text { education, research, services and pharmacy practice? }\end{array}$ & 81 \\
\hline Strategic Plan & $\begin{array}{l}\text { Is your faculty in the process of or has it developed, implemented and regularly } \\
\text { reviewed a strategic plan in order to achieve the mission and goals? }\end{array}$ & 85 \\
\hline $\begin{array}{l}\text { Evaluation of Achievement } \\
\text { of Mission and Goals }\end{array}$ & $\begin{array}{l}\text { Does your faculty have an official document (such as an Evaluation Plan) that } \\
\text { comprehensively describes how the faculty will continuously and systematically } \\
\text { evaluate all aspects of the faculty, including the achievement of its mission and } \\
\text { goals? }\end{array}$ & 58 \\
\hline \multicolumn{3}{|c|}{ Organization and administration } \\
\hline Institutional Accreditation & $\begin{array}{l}\text { Is your faculty accredited by a national / international educational or professional } \\
\text { body? }\end{array}$ & 89 \\
\hline $\begin{array}{l}\text { Faculty and University } \\
\text { Relationship }\end{array}$ & Is your faculty an autonomous unit within the university structure? & 69 \\
\hline $\begin{array}{l}\text { Faculty and Administrative } \\
\text { Relationship }\end{array}$ & $\begin{array}{l}\text { Does your faculty have, within the university structure, autonomous administrative } \\
\text { services related with academic, research and other scholarly activities? }\end{array}$ & 77 \\
\hline $\begin{array}{l}\text { Faculty Organization and } \\
\text { Governance }\end{array}$ & $\begin{array}{l}\text { Does the structure, organization and staffing of the faculty foster the development of } \\
\text { organizational units, allow appropriate allocation of resources and facilitate the } \\
\text { accomplishment of the Faculty's mission and goals? }\end{array}$ & 96 \\
\hline $\begin{array}{l}\text { Dean Qualifications and } \\
\text { Responsibilities }\end{array}$ & $\begin{array}{l}\text { Is your dean a chief administrative and academic officer, having direct access to the } \\
\text { university rector or other university officials delegated, with final responsibility for the } \\
\text { college or faculty? }\end{array}$ & 96 \\
\hline \multicolumn{3}{|l|}{ Curriculum } \\
\hline Goal of Curriculum & $\begin{array}{l}\text { Does the faculty's program curriculum prepare pharmacists for any practice setting } \\
\text { by developing in graduates the knowledge that meets the criteria of good science, } \\
\text { professional skills, attitudes and values, and the ability to integrate and apply } \\
\text { learning to current and future practice? }\end{array}$ & 96 \\
\hline Curricular Development & $\begin{array}{l}\text { Does your curriculum define the expected outcomes and is it developed under the } \\
\text { collective responsibility of the academic teaching staff with attention to sequencing } \\
\text { and integration of contents and selection of teaching methods and assessments? }\end{array}$ & 89 \\
\hline $\begin{array}{l}\text { Teaching and Learning } \\
\text { Methods }\end{array}$ & $\begin{array}{l}\text { Does your faculty use and integrate teaching and learning methods that have been } \\
\text { showed through curricular assessments to produce graduates who became } \\
\text { competent pharmacists with critical thinking, problem-solving and self-directed } \\
\text { lifelong learning skills? }\end{array}$ & 89 \\
\hline Professional Competencies & $\begin{array}{l}\text { Are your graduates able to promote health, provide patient care in cooperation with } \\
\text { all partners based upon good therapeutic principles and evidence-based data that } \\
\text { may influence therapeutic outcomes, manage and use resources of the healthcare } \\
\text { system, and effectively provide, assess and coordinate medication distribution? }\end{array}$ & 92 \\
\hline \multirow[t]{2}{*}{$\begin{array}{l}\text { Knowledge, Skills, Attitudes } \\
\text { and Values }\end{array}$} & $\begin{array}{l}\text { Does your curriculum have all the following areas: fundamental hard sciences, } \\
\text { biomedical sciences, pharmaceutical sciences, social/behavioral/ administrative } \\
\text { sciences and clinical sciences? }\end{array}$ & 100 \\
\hline & $\begin{array}{l}\text { Do graduates possess the required entry-level knowledge, skills, attitudes and } \\
\text { values to practice pharmacy independently by graduation, including the training } \\
\text { period as per the directive of the European Union EC/ 2005/36 http://eur- } \\
\text { lex.europa.eu/LexUriServ/LexUriServ.do?uri=OJ:L:2005:255:0022:0142:en:PDF? }\end{array}$ & 100 \\
\hline \multirow[t]{2}{*}{ Practice Experiences } & $\begin{array}{l}\text { Does your program curriculum include at least } 6 \text { months of traineeship in a } \\
\text { community and / or hospital pharmacy? }\end{array}$ & 92 \\
\hline & $\begin{array}{l}\text { Are the practice experiences within the curriculum appropriately structured and } \\
\text { sequenced to integrate, apply, reinforce and advance the knowledge, skills, attitudes } \\
\text { and values developed through other components of the curriculum? }\end{array}$ & 85 \\
\hline $\begin{array}{l}\text { Assessment and evaluation } \\
\text { of student learning and } \\
\text { curricular effectiveness }\end{array}$ & $\begin{array}{l}\text { Does your faculty use assessment measures throughout the program to evaluate the } \\
\text { attainment of the desired educational outcomes and professional competencies, to } \\
\text { improve student learning and to improve the curriculum and its delivery? }\end{array}$ & 85 \\
\hline \multicolumn{3}{|l|}{ Students } \\
\hline $\begin{array}{l}\text { Organization of student } \\
\text { services }\end{array}$ & $\begin{array}{l}\text { Does your Faculty have organizational elements devoted to student services e.g. a } \\
\text { confidential system of student records; and financial, academic and social support } \\
\text { services for students? }\end{array}$ & 92 \\
\hline
\end{tabular}




\begin{tabular}{|c|c|c|}
\hline & Questions & $\begin{array}{l}\text { Yes } \\
(\%)\end{array}$ \\
\hline $\begin{array}{l}\text { Admission criteria, policies } \\
\text { and procedures }\end{array}$ & $\begin{array}{l}\text { Does your faculty produce and make available to students criteria, policies, and } \\
\text { procedures for admission to the degree program? } \\
\text { Does your faculty have the final responsibility for selection and enrolment (numbers) } \\
\text { of students? }\end{array}$ & 92 \\
\hline Transfer of credits & $\begin{array}{l}\text { Does your faculty use the system of European transfer credits (ECTS) based on } \\
\text { rational procedures and defendable assessments, and make that information } \\
\text { available to students? }\end{array}$ & 100 \\
\hline Progression of students & $\begin{array}{l}\text { Does your faculty produce and make available to students the criteria, policies and } \\
\text { procedures for academic progression? }\end{array}$ & 96 \\
\hline Students complaints policies & $\begin{array}{l}\text { Does your faculty produce and make available to students a complaints policy that } \\
\text { includes elements related to student rights and appeal mechanisms? }\end{array}$ & 96 \\
\hline Program information & $\begin{array}{l}\text { Does your faculty produce and make available to students a complete and accurate } \\
\text { description of the degree program, including its current accreditation status (if } \\
\text { applicable)? }\end{array}$ & 96 \\
\hline $\begin{array}{l}\text { Student representation and } \\
\text { perspectives }\end{array}$ & $\begin{array}{l}\text { Does your faculty involve student representatives on appropriate program } \\
\text { committees, such as accreditation self-studies, assessment, curriculum and strategic } \\
\text { planning? }\end{array}$ & 100 \\
\hline $\begin{array}{l}\text { Professional behavior and } \\
\text { harmonious relationship }\end{array}$ & $\begin{array}{l}\text { Does your faculty provide an environment and culture that promotes professional } \\
\text { behavior and harmonious relationships among students, staff and administrators? }\end{array}$ & 100 \\
\hline \multicolumn{3}{|c|}{ ( } \\
\hline $\begin{array}{l}\text { Faculty staff quantitative } \\
\text { factors }\end{array}$ & $\begin{array}{l}\text { Does your faculty have a sufficient number of qualified full-time staff to effectively } \\
\text { deliver and evaluate the degree program, while providing adequate time for staff } \\
\text { development, research and other activities? }\end{array}$ & 73 \\
\hline $\begin{array}{l}\text { Faculty staff qualitative } \\
\text { factors }\end{array}$ & $\begin{array}{l}\text { Does your faculty have qualified staff with the required professional and academic } \\
\text { expertise and who, individually and collectively, are committed to its mission and } \\
\text { goals? }\end{array}$ & 96 \\
\hline $\begin{array}{l}\text { Faculty staff continuing } \\
\text { professional development } \\
\text { and performance review }\end{array}$ & $\begin{array}{l}\text { Does your faculty have effective programs for performance review and continuing } \\
\text { professional development for full-time, part-time, and voluntary faculty staff, } \\
\text { consistent with their responsibilities in the program? }\end{array}$ & 73 \\
\hline \multicolumn{3}{|l|}{ Facilities and Resources } \\
\hline Physical facilities & $\begin{array}{l}\text { Does your faculty have adequate and appropriate physical facilities and equipment } \\
\text { to achieve its mission and goals? }\end{array}$ & 73 \\
\hline Practice facilities & $\begin{array}{l}\text { Does your faculty have criteria for the selection of its practice sites and work } \\
\text { collaboratively with those sites to advance the patient care services provided there? }\end{array}$ & 73 \\
\hline $\begin{array}{l}\text { Library and educational } \\
\text { resources }\end{array}$ & $\begin{array}{l}\text { Does your faculty ensure access for all staff and students to a library and other } \\
\text { educational resources, sufficient to support the degree program and to provide for } \\
\text { research and other activities in accordance with its mission and goals? }\end{array}$ & 100 \\
\hline Financial resources & $\begin{array}{l}\text { Does your faculty have the financial resources necessary to accomplish its mission } \\
\text { and goals? }\end{array}$ & 46 \\
\hline
\end{tabular}

\begin{tabular}{|c|c|c|c|}
\hline \multicolumn{3}{|c|}{ Table 2. Distribution of the empirical QA indicator } \\
\hline \multicolumn{4}{|c|}{ QA score } \\
\hline $\begin{array}{c}\text { Yes } \\
\text { responses }\end{array}$ & $\begin{array}{c}\text { Surveys } \\
\text { (number) }\end{array}$ & $\begin{array}{c}\text { Frequency of } \\
\text { yes responses } \\
\%\end{array}$ & $\begin{array}{c}\text { Cumulative } \\
\%\end{array}$ \\
\hline 22 & 2 & 7.7 & 7.7 \\
\hline 23 & 1 & 3.8 & 11.5 \\
\hline 24 & 1 & 3.8 & 15.3 \\
\hline 26 & 1 & 3.8 & 19.1 \\
\hline 27 & 1 & 3.8 & 22.9 \\
\hline 28 & 6 & 23.2 & 46.1 \\
\hline 29 & 6 & 23.2 & 69.3 \\
\hline 30 & 2 & 7.7 & 77.0 \\
\hline 31 & 1 & 3.8 & 80.8 \\
\hline 32 & 2 & 7.7 & 88.5 \\
\hline 33 & 3 & 11.5 & 100 \\
\hline Total & 26 & 100 & \\
\hline
\end{tabular}

